\title{
Combined zinc and nitrogen applications at panicle initiation for zinc biofortification in rice
}

\author{
SHAHID HUSSAIN ${ }^{1}$ \\ KIRAN SAHAR ${ }^{1}$ \\ ASIF NAEEM ${ }^{2}$ \\ MUHAMMAD ZAFAR-UL-HYE ${ }^{1}$ \\ MUHAMMAD AON ${ }^{1}$ \\ ${ }^{1}$ Department of Soil Science, Faculty of Agricultural \\ Sciences and Technology, Bahauddin Zakariya \\ University, Multan (Pakistan) \\ ${ }^{2}$ Soil and Environmental Sciences Division, Nuclear \\ Institute for Agriculture and Biology, Faisalabad \\ (Pakistan)

\section{Correspondence \\ Shahid Hussain \\ E-mail: shahid.hussain@bzu.edu.pk}

Keywords: alkaline soil; foliar fertilisation; grain zinc density

\begin{abstract}
Background and purpose: Increasing zinc $(Z n)$ concentration in rice grains can help improve $Z n$ nutrition of people. The combinations of $Z n$ and nitrogen $(N)$ applications at panicle initiation were investigated for $Z n$ biofortification in rice.
\end{abstract}

Materials and methods: Rice (cv. Super Basmati) seedling were grown in pots having a calcareous soil. All combinations of four Zn (control, Soil $6 \mathrm{mgZn} \mathrm{kg}$, foliar $2 \times 0.2 \% \mathrm{Zn}$ and soil + foliar $Z n$ ) and three $N$ (control,

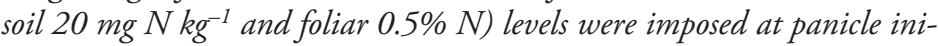
tiation. At maturity, grains analysed for $Z n$ and proteins.

Results: Grain protein concentration was significantly increased with foliar $Z n$ treatments, and with soil and foliar N. Maximum grain $Z n$ concertation (30 $\left.\mathrm{mg} \mathrm{kg}^{-1}\right)$ was achieved with application of soil Zn + foliar $Z n+$ foliar N. At each N level, Zn application by either method significantly increased grain $Z n$ concentration over control. This increase in grain $Z n$ concertation at $N$ levels was 36 to $54 \%$ with soil $Z n+$ foliar $Z n, 27$ to $45 \%$ with foliar $Z n$ and 9 to $15 \%$ with soil $Z n$ over its control level.

Conclusions: Grain $Z n$ concentration was significantly increased with soil $N$ when combined with soil $Z n$, and with foliar $N$ when combined with foliar Zn treatments. Conclusively, foliar $N$ combined with soil + foliar $Z n$ is the best combination of late $Z n$ and $N$ application for agronomic $Z n$ biofortification in rice.

\section{INTRODUCTION}

I acking the affordability to a diversified food, people in many counLtries primarily rely on cereal grains to sustain their lives. Over time, intensive agriculture has depleted nutrients from soils (1) resulting in a poor nutritional quality of cereal grains produced from these soils. Moreover, the green revolution in the 1960s led to the development of high yielding cereal cultivars that have lower mineral density than old cultivars $(2,3)$. As a consequence, people are encountering undernourishment of iron $(\mathrm{Fe})$, zinc $(\mathrm{Zn})$ and several other nutrients.

Zinc deficiency causes human health problems such as poor physical growth, weak immune system, low learning ability and deoxyribonucleic acid damage. Zinc biofortification of staple crops, both genetic and agronomic, is a promising approach and it has gained due perception by Consultative Group on International Agricultural Research (4). Wheat, rice, and maize are important cereal crops that are the targets of $\mathrm{Zn}$ biofortification as being consumed mainly in countries having $\mathrm{Zn}$ deficiency in human populations. In rice grains, efforts are being made to
Revised November 03, 2018.

Accepted November 03, 2018. 
increase the current baseline $\mathrm{Zn}$ level of $16 \mathrm{mg} \mathrm{kg}^{-1}$ to an acceptable level of $28 \mathrm{mg} \mathrm{kg}^{-1}$.

Alkaline calcareous soils and flooded field conditions in the rice production systems in Asia decrease the availability of soil $\mathrm{Zn}$ to growing rice plants (5). Not only the yield but also the quality of the produced grains is low under such production systems. Other factors contributing to low $\mathrm{Zn}$ availability from soil are low organic matter, high phosphate application and salt stress (6). Agronomic biofortification by $\mathrm{Zn}$ application may simultaneously increase grain yield and grain $\mathrm{Zn}$ concentration in both standard and biofortified cultivars of cereals (7). Zinc application by different methods significantly improved grain $\mathrm{Zn}$ concentration in rice (8-10). Grain $\mathrm{Zn}$ concentration is enhanced more with foliar application of $\mathrm{Zn}$ during flowering and grain development stages than other methods of $\mathrm{Zn}$ application to the rice crop.

Zinc in grains is localized with proteins (11). Application of $\mathrm{N}$, both as basal and late dose, is known to increase root uptake, root-to-shoot translocation and remobilization of $\mathrm{Zn}$ (12). For $\mathrm{Zn}$ biofortification in rice, combined applications of $\mathrm{Zn}$ and $\mathrm{N}$ to rice are more important than their sole applications (13). However, it is still unknown if soil or foliar application of $\mathrm{N}$ at panicle initiation will be a better combination with different application methods of $\mathrm{Zn}$ to rice. The specific objectives of the experiment were to investigate: (i) the effect of late $\mathrm{Zn}$ and $\mathrm{N}$ applications on grain protein concentration and (ii) the best combination of $\mathrm{Zn}$ and $\mathrm{N}$ applications for $\mathrm{Zn}$ biofortification in rice.

\section{MATERIAL AND METHODS}

A pot experiment was conducted in a glasshouse at Department of Soil Science, Bahauddin Zakariya University, Multan (Pakistan). Soil for the study was collected from the surface layer $(0-30 \mathrm{~cm}$ soil depth) of a field of at Agricultural Research Farm of the university. The soil was air-dried, crushed, and passed through a 2 $\mathrm{mm}$ sieve. A representative subsample of the soil was analysed for basic characteristics following standard methods $(14,15)$. The clay loam (determined by Hydrometer method) had sand, silt, and clay contents of 26, 40 and 34\%, respectively. The soil was alkaline calcareous in nature having $\mathrm{pH} 7.8$ in saturated soil paste and 4\% w/w acid neutralizable free $\mathrm{CaCO}_{3}$. The electrical conductivity of soil saturated paste extract (EC), organic matter content and DTPA-extractable $\mathrm{Zn}$ of soil were $2.4 \mathrm{dS} \mathrm{m}^{-1}, 0.5 \%$ $\mathrm{w} / \mathrm{w}, 0.7 \mathrm{mg} \mathrm{kg}^{-1}$, respectively.

Each of 36 polyethylene lined plastic pot was filled in with $10 \mathrm{~kg}$ of the soil. Rice (cv. Super Basmati) seedlings ( $25 \mathrm{~d}$ old) were purchased from the local market. Three pairs of healthy seedlings of uniform height were transplanted in each pot in the last week of July 2016. A basal dose of nitrogen $\left(25 \mathrm{mg} \mathrm{kg}^{-1}\right.$ soil), phosphorus $(25 \mathrm{mg}$ $\mathrm{kg}^{-1}$ soil) and potassium (31 $\mathrm{mg} \mathrm{kg}^{-1}$ soil) was applied as urea $\left[\left(\mathrm{NH}_{2}\right)_{2} \mathrm{CO}\right]$ and potassium di-hydrogen phosphate
$\left(\mathrm{KH}_{2} \mathrm{PO}_{4}\right)$, respectively. After transplantation, water level in the pots was kept about $3 \mathrm{~cm}$ above the soil for the first 14 days, and then progressively increased to $5 \mathrm{~cm}$ height. For this purpose, tube-well water of good irrigation quality $\left(\mathrm{pH} 7.8, \mathrm{EC} 0.34 \mathrm{dS} \mathrm{m}^{-1}\right.$, and undetectable $\mathrm{Zn}$ concentration) was used. All pots were randomized every 6th day to avoid the differential effects of microclimate in the glasshouse. Second and third splits of N, each of $25 \mathrm{mg} \mathrm{kg}^{-1}$ soil, were applied after 3 and 6 weeks of transplantation, respectively.

Experiment had twelve treatments in total, i.e. all possible combinations of four $\mathrm{Zn}$ levels (control, soil application at $6 \mathrm{mg} \mathrm{Zn} \mathrm{kg}^{-1}, 2$ foliar sprays of $0.2 \% \mathrm{w} / \mathrm{v} \mathrm{Zn}$ solution and soil + foliar application) and three $\mathrm{N}$ levels (control, soil application at $20 \mathrm{mg} \mathrm{N} \mathrm{kg}^{-1}$ and foliar spray of $0.5 \% \mathrm{w} / \mathrm{v} \mathrm{N}$ ) were applied at panicle emergence stage of rice. These fertiliser treatments were of urea $\left[\left(\mathrm{NH}_{2}\right)_{2} \mathrm{CO}\right]$ and hydrated zinc sulphate $\left(\mathrm{ZnSO}_{4} \cdot 7 \mathrm{H}_{2} \mathrm{O}\right)$ and were applied additionally to the basal applications of macronutrient fertilisers. The treatments were arranged in completely randomized factorial design with three replications.

Irrigation was stopped a week before the harvest of the crop at maturity. Straws and panicles were cut and collected in separate paper bags. The plant samples were kept in an oven at $65^{\circ} \mathrm{C}$ till constant weight and this was followed by the recording of straw and grains dry weights. Unhusked rice grains were dry ashed in a muffle furnace at $550^{\circ} \mathrm{C}$ followed by dissolution in $5 \mathrm{~N}$ hydrochloric acid $(\mathrm{HCl})$ and dilution with distilled water (16). Zinc in the digests was analysed on an atomic absorption spectrometer (Thermo Scientific 3000 Series, Waltham, MA, USA). For determination of N, separate samples of unhulled grains were digested on a hot plate with sulfuric acid $\left(\mathrm{H}_{2} \mathrm{SO}_{4}\right)$ and hydrogen peroxide (16). In wet-digested samples, a colour was developed with Nessler's reagent and absorbance was measured on a spectrophotometer (UV-1602, BMS, Quebec, Canada) $425 \mathrm{~nm}$ (17). A factor of 5.7 was used to convert total $\mathrm{N}$ measurements to concentration of raw protein in grains.

Statistical significance $(P \leq 0.05)$ of main and interactive effects of treatments on the recorded parameters was tested by two-way analyses of variance (ANOVA) test with interactions. The significant difference among measured was determined by Tukey's HSD test. All statistical analyses were carried out on SAS University Edition (SAS/STAT ${ }^{\oplus}$, SAS Institute Inc., NC, USA).

\section{RESULTS}

\section{Rice yield}

Main effects of $\mathrm{Zn}$ and $\mathrm{N}$ significantly $(P \leq 0.05)$ influenced grain and straw yield of rice (Table 1$)$. As compared to $\mathrm{Zn}$-control, grain and straw yields were increased by $\mathrm{Zn}$ application to the soil (Table 2). With soil $\mathrm{Zn}$ alone and Soil $\mathrm{Zn}+$ foliar $\mathrm{Zn}$, grain yield increased respective- 
ly by 7 and $9 \%$ while that of straw yield by about $7 \%$. Foliar-applied $\mathrm{Zn}$ did not affect straw or grain yield.

As compared to control level of $\mathrm{N}$, grain and straw yields were increased by about $5 \%$ each with foliar-applied $\mathrm{N}$ and by 11 and $9 \%$, respectively with soil-applied $\mathrm{N}$ (Table 2). In contrast to straw yield, grain yield was more with soil application of $\mathrm{N}$ than its foliar application.

\section{Grain protein}

Main effects of both $\mathrm{Zn}$ and $\mathrm{N}$ significantly $(P \leq 0.05)$ influenced concentration and contents of raw protein in grains (Table 1). However, variance in concentration and contents of grain protein was contributed more by $\mathrm{N}$ than Zn application.

Soil application of $\mathrm{Zn}$ did not affect grain protein concertation while foliar application alone or in combination with soil $\mathrm{Zn}$ increased grain protein concertation by $4 \%$

Table 1. Outcome (F values) of two-way analysis of variance (ANOVA) test

\begin{tabular}{|lccc|}
\hline \multirow{2}{*}{ Parameter } & \multicolumn{3}{c|}{ Source of variation } \\
\cline { 2 - 4 } & $\mathrm{Zn}$ & $\mathrm{N}$ & $\mathrm{Zn} \times \mathrm{N}$ \\
\hline Grain yield & $3^{*}$ & $11^{*}$ & 1 \\
Straw yield & $3^{*}$ & $9^{*}$ & 1 \\
Grain protein concentration & $4^{*}$ & $53^{*}$ & 1 \\
Grain protein contents & $5^{* *}$ & $37^{*}$ & 1 \\
Grain Zn concentration & $161^{*}$ & $19^{*}$ & $6^{*}$ \\
Grain Zn contents & $65^{*}$ & $22^{*}$ & 2 \\
\hline
\end{tabular}

Asterisk $\left(^{*}\right)$ denotes significant effect at $P \leq 0.05$.

Table 2. Yield response of rice grown in pots and fertilised, at panicle emergence stage, with all combinations of four zinc $(Z n)$ levels and three nitrogen $(N)$ levels

\begin{tabular}{|lcc|}
\hline Treatment levels & $\begin{array}{c}\text { Grain yield } \\
\left(\mathrm{g} \mathrm{pot}^{-1}\right)\end{array}$ & $\begin{array}{c}\text { Straw yield } \\
\left(\mathrm{g} \mathrm{pot}^{-1}\right)\end{array}$ \\
\hline Main effect of Zn levels & & \\
\hline Control Zn & $5.5 \pm 0.4 \mathrm{~B}$ & $16.1 \pm 1.2 \mathrm{~B}$ \\
Soil Zn $\left(6 \mathrm{mg} \mathrm{Zn} \mathrm{kg}{ }^{-1}\right)$ & $5.9 \pm 0.2 \mathrm{~A}$ & $17.0 \pm 0.8 \mathrm{~A}$ \\
Foliar Zn $(0.2 \% \mathrm{w} / \mathrm{v} \mathrm{Zn})$ & $5.7 \pm 0.4 \mathrm{AB}$ & $16.5 \pm 1.2 \mathrm{AB}$ \\
Soil Zn $\left.(6 \mathrm{mg} \mathrm{Zn} \mathrm{kg})^{-1}\right)$ & $6.0 \pm 0.5 \mathrm{~A}$ & $17.1 \pm 0.9 \mathrm{~A}$ \\
Foliar Zn $(0.2 \% \mathrm{w} / \mathrm{v} \mathrm{Zn})$ & & \\
\hline Main effect of N levels & & $15.9 \pm 0.9 \mathrm{~B}$ \\
\hline Control N & $5.5 \pm 0.3 \mathrm{C}$ & $17.4 \pm 0.7 \mathrm{~A}$ \\
Soil N $\left(20 \mathrm{mg} \mathrm{kg}{ }^{-1}\right.$ soil $)$ & $6.1 \pm 0.3 \mathrm{~A}$ & $16.7 \pm 1.2 \mathrm{~A}$ \\
\hline Foliar N $(0.5 \% \mathrm{w} / \mathrm{v} \mathrm{N})$ & $5.8 \pm 0.4 \mathrm{~B}$ & \\
\hline
\end{tabular}

Means \pm standard deviations; Separately for each main effect, different letters indicate significant $(\mathrm{P} \leq 0.05)$ differences based on Tukey's HSD.
Table 3. Concentration and contents of raw proteins in grains of rice grown in pots and fertilised, at panicle emergence stage, with all combinations of four zinc $(\mathrm{Zn})$ levels and three nitrogen $(N)$ levels

\begin{tabular}{|c|c|c|}
\hline Treatment levels & $\begin{array}{l}\text { Grain protein } \\
\text { concertation } \\
\quad\left(\mathrm{g} \mathrm{kg}^{-1}\right)\end{array}$ & $\begin{array}{c}\text { Grain protein } \\
\text { content } \\
\left(\mathrm{mg} \mathrm{pot}^{-1}\right)\end{array}$ \\
\hline \multicolumn{3}{|l|}{ Main effect of $\mathrm{Zn}$ levels } \\
\hline Control Zn & $76 \pm 5 \mathrm{~B}$ & $423 \pm 53 \mathrm{~B}$ \\
\hline Soil $\mathrm{Zn}\left(6 \mathrm{mg} \mathrm{Zn} \mathrm{kg}^{-1}\right)$ & $77 \pm 5 \mathrm{AB}$ & $457 \pm 43 \mathrm{~A}$ \\
\hline Foliar $\mathrm{Zn}(0.2 \% \mathrm{Zn} \mathrm{w} / \mathrm{v})$ & $79 \pm 4 \mathrm{~A}$ & $455 \pm 43 \mathrm{~A}$ \\
\hline $\begin{array}{l}\text { Soil Zn }\left(6 \mathrm{mg} \mathrm{Zn} \mathrm{kg}^{-1}\right)+ \\
\text { Foliar } \mathrm{Zn}(0.2 \% \mathrm{Zn} \mathrm{w} / \mathrm{v})\end{array}$ & $79 \pm 4 \mathrm{~A}$ & $469 \pm 54 \mathrm{~A}$ \\
\hline \multicolumn{3}{|l|}{ Main effect of $\mathrm{N}$ levels } \\
\hline Control N & $73 \pm 3 \mathrm{~B}$ & $399 \pm 28 \mathrm{C}$ \\
\hline Soil $\mathrm{N}$ (20 $\mathrm{mg} \mathrm{kg}^{-1}$ soil) & $80 \pm 2 \mathrm{~A}$ & $489 \pm 29 \mathrm{~A}$ \\
\hline Foliar N $(0.5 \% \mathrm{~N}$ w/v $)$ & $80 \pm 2 \mathrm{~A}$ & $464 \pm 38 \mathrm{~B}$ \\
\hline
\end{tabular}

Means \pm standard deviations; Separately for each main effect, different letters indicate significant $(\mathrm{P} \leq 0.05)$ differences based on Tukey's HSD.

each over control level of $\mathrm{Zn}$ (Table 3). Zinc application, by any method, increased grain protein contents over control level of $\mathrm{Zn}$; the increase ranged from 8 to $11 \%$. The differences in both concentration and contents of grain protein were non-significant $(P \leq 0.05)$ at three applied levels of $\mathrm{Zn}$.

Nitrogen application by either method significantly $(P \leq 0.05)$ increased concentration (by about $11 \%$ each with soil and foliar application of $\mathrm{N}$ ) and contents (by about 23 and $16 \%$ respectively with soil and foliar-applied $\mathrm{N}$ ) of protein in grains (Table 3). The contents of protein in grains were significantly $(P \leq 0.05)$ less with soil-applied $\mathrm{N}$ than its foliar application.

\section{Grain zinc}

Grain Zn concertation ranged from 19 to $30 \mathrm{mg} \mathrm{kg}^{-1}$ among twelve treatments comprising of all combinations of four $\mathrm{Zn}$ and three $\mathrm{N}$ levels (Figure 1). Grain $\mathrm{Zn}$ concentration was significantly $(P \leq 0.05)$ influenced by main and interactive effects of $\mathrm{N}$ and $\mathrm{Zn}$ applications at panicle initiation (Table 1). At each level of $\mathrm{N}$, application of $\mathrm{Zn}$ by any method significantly $(P \leq 0.05)$ increased grain $\mathrm{Zn}$ concentration over control Zn (Figure 1). Similarly, at each level of $\mathrm{N}$, the maximum increase in grain $\mathrm{Zn}$ concertation was achieved with combined soil + foliar $\mathrm{Zn}$ (36 to $54 \%$ ) followed by foliar $\mathrm{Zn}$ alone (27 to $45 \%$ ) and then soil $\mathrm{Zn}$ alone (9 to $15 \%$ ).

At control level of $\mathrm{Zn}$, the application of $\mathrm{N}$, either to soil or on foliage, had a non-significant effect on grain $\mathrm{Zn}$ concertation over control level of N (Figure 1). Soil N increased grain $\mathrm{Zn}$ concentration over control level of $\mathrm{N}$ only when combined with soil $\mathrm{Zn}$ application. Foliar N 


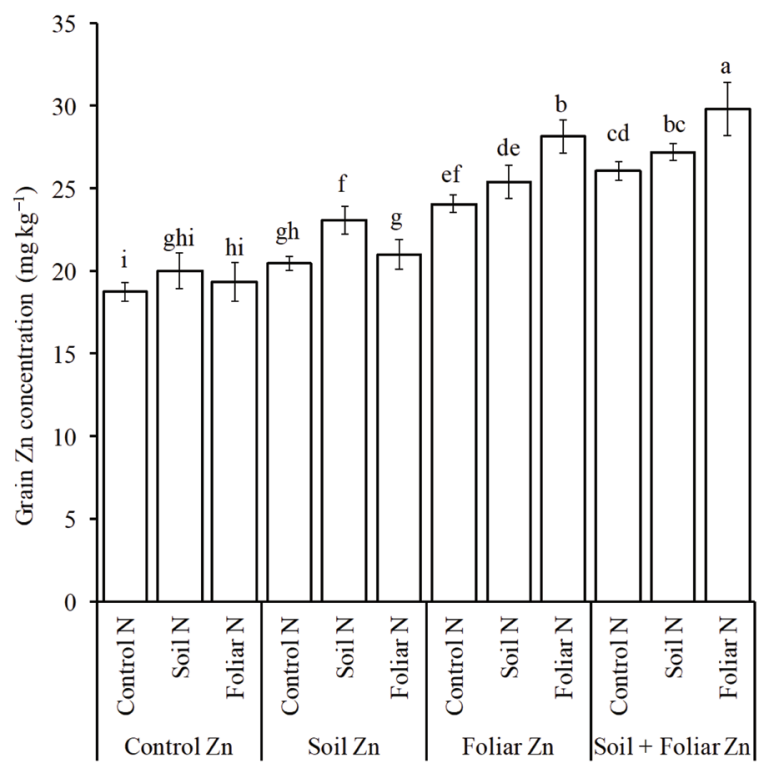

Figure 1. Concentration of zinc $\left(Z_{n}\right)$ in grains of rice grown in pots and fertilised, at panicle emergence stage, with all possible combinations of four $\mathrm{Zn}$ levels [control, soil application ( $6 \mathrm{mg} \mathrm{Zn} \mathrm{kg}^{-1}$ ), foliar spray $(2 \times 0.2 \% \mathrm{w} / \mathrm{V} \mathrm{Zn})$ and soil + foliar application] and three nitrogen ( $N)$ levels [control, soil application $\left(20 \mathrm{mg} \mathrm{N} \mathrm{kg}^{-1}\right.$ ) and foliar spray $(0.5 \% \mathrm{w} / \mathrm{N})$ ). Error bars are of standard deviations. Different letters on the bars indicate significant $(P \leq 0.05)$ differences based on Tukey's HSD.

increased grain $\mathrm{Zn}$ concentration over control level of $\mathrm{N}$ only when combined with treatments having foliar $\mathrm{Zn}$ application. Maximum grain $\mathrm{Zn}$ concertation was achieved with foliar $\mathrm{N}$ application to pots supplied with combined soil + foliar Zn applications.

Only main effects of $\mathrm{N}$ and $\mathrm{Zn}$ were significant $(P \leq 0.05)$ for grain $\mathrm{Zn}$ contents (Table 4$)$. As compared to control level of $\mathrm{Zn}$, application of $\mathrm{Zn}$ by either method increased grain $\mathrm{Zn}$ contents producing maximum value with soil + foliar-applied Zn. Similar to grain Zn concentration, $\mathrm{Zn}$ contents were mainly increased by the treatments having foliar $\mathrm{Zn}$ applications; an increase of 38 and $53 \%$ respectively was recorded by foliar alone and soil + foliar applications of $\mathrm{Zn}$ over control level of $\mathrm{Zn}$.

\section{DISCusSION}

Soil $\mathrm{Zn}$ application, and both soil and foliar $\mathrm{N}$ applications at panicle initiation significantly $(P \leq 0.05)$ increased straw and grain yield of rice (Table 2 ). This is because plants require a continuous supply of most of the nutrients throughout their life cycle. The level of yield response by a crop, however, is dependent on the rate, source, method and time of fertilizer application (18). In the present study, $\mathrm{Zn}$ and $\mathrm{N}$ were applied at panicle initiation on $50 \%$ of main-tillers. During treatment application, therefore, many subtillers might have been in vegetative growth. A growth response was therefore expected especially due to the reason that soil was low in plant-available $\mathrm{Zn}$ and previously applied $\mathrm{N}$ might have already used by plant or lost in the environment. Moreover, $\mathrm{N}$ application at panicle initiation stage of rice increases grain yield by increasing grain weight in inferior spikelets (19). However, application of $\mathrm{N}$ at late vegetative stage delays maturity and increases chances of lodging (20). Therefore, field optimisation of rate and exact time of $\mathrm{N}$ application must to studied for economic yield returns along with quality grains.

Efforts have been done to increase protein and mineral densities in rice grains by conventional plant breeding and genetic engineering. Along with environmental protection and higher yields, agronomic fertiliser management is also meant to produce nutritious plant-based foods. For example, $\mathrm{N}$ fertilisation increased $\mathrm{Zn}$ and protein contents in rice grains along with an increase in grain yield (21). In the present study, soil $\mathrm{N}$ fertilisation at panicle initiation also played a positive role in increasing grain protein concentration and contents in rice (Table 3). Application of $\mathrm{N}$ to cereals also increases grain accumulation of $\mathrm{Zn}$ by an increased sink in the form of waterinsoluble proteins $(22,23)$. Other reasons for increased grain $\mathrm{Zn}$ concentration by $\mathrm{N}$ application include increased uptake by the intensified root system, and better translocation and remobilisation of $\mathrm{Zn}$ towards grains $(24,25)$. Therefore, a suitable quantity of $\mathrm{N}$ fertilizer at the flowering stage of rice is an important measure to obtain higher grain protein and grain $\mathrm{Zn}$ concentration.

Similar to N, the application of $\mathrm{Zn}$ also increases protein and $\mathrm{Zn}$ concentration in rice grains. Soil application, seed priming and foliar application are recommended to both flooded and direct seeded rice for this purpose (9).

Table 4. Contents of zinc $(\mathrm{Zn})$ in grains of rice grown in pots and fertilised, at panicle emergence stage, with all possible combinations of four $Z n$ levels and three nitrogen $(N)$ levels

\begin{tabular}{|lc|}
\hline Treatment levels & Grain zinc content $\left(\mathrm{mg} \mathrm{pot}^{-1}\right)$ \\
\hline Main effect of Zn levels & \\
\hline Control Zn & $108 \pm 12 \mathrm{D}$ \\
Soil Zn $\left(6 \mathrm{mg} \mathrm{Zn} \mathrm{kg}{ }^{-1}\right)$ & $128 \pm 10 \mathrm{C}$ \\
Foliar Zn $\left(0.2 \% \mathrm{Zn} \mathrm{w}^{\mathrm{v}}\right)$ & $149 \pm 15 \mathrm{~B}$ \\
Soil $\left.\mathrm{Zn}(6 \mathrm{mg} \mathrm{Zn} \mathrm{kg})^{-1}\right)$ & $165 \pm 19 \mathrm{~A}$ \\
Foliar Zn $\left(0.2 \% \mathrm{Zn} \mathrm{w}_{\mathrm{v}}\right)$ & \\
\hline Main effect of N levels & $123 \pm 19 \mathrm{~B}$ \\
\hline Control N & $146 \pm 22 \mathrm{~A}$ \\
Soil N $\left(20 \mathrm{mg} \mathrm{kg}{ }^{-1}\right.$ soil $)$ & $142 \pm 31 \mathrm{~A}$ \\
Foliar N $(0.5 \% \mathrm{~N} \mathrm{w} / \mathrm{v})$ & \\
\hline
\end{tabular}

Means \pm standard deviations; Separately for each main effect, different letters indicate significant $(\mathrm{P} \leq 0.05)$ differences based on Tukey's HSD. 
Zinc influences several physiological functions like synthesis, integrity and functioning of proteins in plants (26). Moreover, $\mathrm{Zn}$ application might influence the uptake and translocation of $\mathrm{N}$ in rice plants (13). Therefore, $\mathrm{Zn}$ application increased concentration and contents of protein in rice grains (Table 4).

From soil-applied $\mathrm{Zn}$ fertiliser, soil $\mathrm{Zn}^{2+}$ ion rapidly forms precipitates of zinc carbonate $\left(\mathrm{ZnCO}_{3}\right)$ under alkaline calcareous soils (27). Therefore, recovery of soil-applied $\mathrm{Zn}$ is limited in high $\mathrm{pH}$ calcareous soils. Moreover, the availability of applied $\mathrm{Zn}$ decreases over time (28). Therefore, late applications of $\mathrm{Zn}$, especially in foliar form, are ideal for efficient uptake by plants. Late soil applications are also justifiable as a major fraction of $\mathrm{Zn}$ in grains is as a result of $\mathrm{Zn}$ uptake by roots after flowering stage (29). Soil $\mathrm{Zn}$ application combined two foliar $\mathrm{Zn}$ applications at flowering are suggested by researchers for effective $\mathrm{Zn}$ biofortification in rice $(13,30)$. Foliar $\mathrm{Zn}$ sprays are important as $\mathrm{Zn}$ is not fixed in soils and it has to travel little from leaf to grain as comparison to the soil where it travels from roots to grain (31).

In the present study, soil $\mathrm{N}$ increased grain $\mathrm{Zn}$ concentration if combined soil $\mathrm{Zn}$ and foliar $\mathrm{N}$ application increased grain $\mathrm{Zn}$ concentration if combined with treatments having foliar $\mathrm{Zn}$ (Figure 1). Zinc translocate through xylem as $\mathrm{Zn}$-phytosiderophore or $\mathrm{Zn}$-amino acid and in phloem as $\mathrm{Zn}$-nicotinamine complexes (32). These organic compounds have $\mathrm{N}$ as their integral part. For $\mathrm{N}$ fertilized soils, therefore, the cotransport of $\mathrm{Zn}$ with $\mathrm{N}$ seems important for increased grain $\mathrm{Zn}$ accumulation by $\mathrm{N}$ application.

\section{CONCLUSIONS}

At panicle initiation, application of $\mathrm{Zn}$ and $\mathrm{N}$ increased concentrations of protein and $\mathrm{Zn}$ in rice grains. Results suggested that grain $\mathrm{Zn}$ concentration is significantly $(P \leq 0.05)$ increased over respective control when both $\mathrm{Zn}$ and $\mathrm{N}$ were combined to soil or on foliage. This suggests that the role of $\mathrm{N}$ in $\mathrm{Zn}$ uptake, absorption, translation, and remobilisation is important for cotransport of $\mathrm{Zn}$ with N. Foliar + soil $\mathrm{Zn}$ when combed with foliar $\mathrm{N}$ increased grain $\mathrm{Zn}$ concertation to an acceptable level of $\mathrm{Zn}$ biofortification in rice.

\section{ACKNOWLEDGEMENTS}

The study was supported by Bahauddin Zakariya University, Multan (Pakistan).

\section{DECLARATION}

Authors declare no competing interests.

\section{REFERENCES}

1. VANLAUWE B, SIX J, SANGINGA N, ADESINA AA 2015 Soil fertility decline at the base of rural poverty in sub-Saharan Africa. Nat Plants 1(7): 15101. https://doi.org/10.1038/nplants.2015.101

2. HUSSAIN S, MAQSOOD MA, RENGEL Z, KHAN MK 2012 Mineral bioavailability in grains of Pakistani bread wheat declines from old to current cultivars. Euphytica 186(1): 153-163. https://doi.org/10.1007/s10681-011-0511-1

3. FAN M-S, ZHAO F-J, FAIRWEATHER-TAIT SJ, POULTON PR, DUNHAM SJ, MCGRATH SP 2008 Evidence of decreasing mineral density in wheat grain over the last 160 years. J Trace Elem Med Biol 22(4): 315-24. https://doi.org/10.1016/j.jtemb.2008.07.002

4. BOUIS HE, SALTZMAN A 2017 Improving nutrition through biofortification: A review of evidence from HarvestPlus, 2003 through 2016. Glob Food Sec 12(January): 49-58. https://doi.org/10.1016/j.gfs.2017.01.009

5. DUFFNER A, HOFFLAND E, STOMPH TJ, MELSE-BOONSTRA A, BINDRABAN PS 2014 Elimination zinc deficiency in rice-based systems (VFRC Report 2014/2), Washington, D.C.

6. ALLOWAY B 2009 Soil factors associated with zinc deficiency in crops and humans. Environ Geochem Health 31(5): 537-548. https://doi.org/10.1007/s10653-009-9255-4

7. QASWAR M, HUSSAIN S, RENGEL Z 2017 Zinc fertilisation increases grain zinc and reduces grain lead and cadmium concentrations more in zinc-biofortified than standard wheat cultivar. Sci Total Environ 605-606: 454-460. https://doi.org/10.1016/j.scitotenv.2017.06.242

8. RAM H, RASHID A, ZHANG W, DUARTE AP, PHATTARAKUL N, SIMUNJI S, KALAYCI M, FREITAS R, RERKASEM B, BAL RS, MAHMOOD K, SAVASLI E, LUNGU O, WANG ZH, BARROS VLNP DE, MALIK SS, ARISOY RZ, GUO JX, SOHU VS, ZOU CQ, CAKMAK I 2016 Biofortification of wheat, rice and common bean by applying foliar zinc fertilizer along with pesticides in seven countries. Plant Soil 403(1): 389-401. https://doi.org/10.1007/s11104-016-2815-3

9. FAROOQ M, ULLAH A, REHMAN A, NAWAZ A, NADEEM A, WAKEEL A, NADEEM F, SIDDIQUE KHM 2018 Application of zinc improves the productivity and biofortification of fine grain aromatic rice grown in dry seeded and puddled transplanted production systems. F Crop Res 216: 53-62. https://doi.org/10.1016/j.fcr.2017.11.004

10. IMRAN M, KANWAL S, HUSSAIN S, AZIZ T, MAQSOOD MAMA 2015 Efficacy of zinc application methods for concentration and estimated bioavailability of zinc in grains of rice grown on a calcareous soil. Pakistan J Agric Sci 52(1): 169-175

11. PERSSON DP, BANG TC DE, PEDAS PR, KUTMAN UB, CAKMAK I, ANDERSEN B, FINNIE C, SCHJOERRING JK, HUSTED S 2016 Molecular speciation and tissue compartmentation of zinc in durum wheat grains with contrasting nutritional status. New Phytol 211(4): 1255-1265. https://doi.org/10.1111/nph.13989

12. ERENOGLU EB, KUTMAN UB, CEYLAN Y, YILDIZ B, CAKMAK I 2011 Improved nitrogen nutrition enhances root uptake, root-to-shoot translocation and remobilization of zinc $\left({ }^{65} \mathrm{Zn}\right)$ in wheat. New Phytol 189(2): 438-448. https://doi.org/10.1111/j.1469-8137.2010.03488.x

13. GUO JX, FENG XM, HU XY, TIAN GL, LING N, WANG JH, SHEN QR, GUO SW 2016 Effects of soil zinc availability, nitrogen fertilizer rate and zinc fertilizer application method on zinc biofortification of rice. J Agric Sci 154(4): 584-597. https://doi.org/10.1017/S0021859615000441

14. SPARKS DL, PAGE AL, SUMNER ME, TABATABAI MA, HELMKE PA 1996 Methods of Soil Analysis - Part 3. Chemical Methods, Soil Science Society of America, Madison, USA 
15. KLUTE A 1986 Methods of soil analysis. Part 1. Physical and mineralogical methods., American Society of Agronomy, Inc., Madison. https://doi.org/10.2136/sssabookser5.1.2ed.c9

16. JONES JB, CASE VW 1990 Sampling, handling and analyzing plant tissue samples, In: Westerman R L (ed) Soil Testing and Plant Analysis, Soil Science Society of America, Madison, USA, p 389

17. GINKEL JH VAN, SINNAEVE J 1980 Determination of total nitrogen in plant material with Nessler's reagent by continuousflow analysis. Analyst 105(1257): 1199.

https://oi.org/10.1039/an9800501199

18. XU X, HE P, QIU S, PAMPOLINO M F, ZHAO S, JOHNSTON AM, ZHOU W 2014 Estimating a new approach of fertilizer recommendation across small-holder farms in China. F Crop Res 163: 10-17. https://doi.org/10.1016/j.fcr.2014.04.014

19. JIANG Q, DU Y, TIAN X, WANG Q, XIONG R, XU G, YAN C, DING Y 2016 Effect of panicle nitrogen on grain filling characteristics of high-yielding rice cultivars. Eur J Agron 74: 185-192. https://doi.org/10.1016/j.eja.2015.11.006

20. CORBIN JL, ORLOWSKI JM, HARRELL DL, GOLDEN BR, FALCONER L, KRUTZ LJ, GORE J, COX MS, WALKER TW 2016 Nitrogen strategy and seeding rate affect rice lodging, yield, and economic returns in the midsouthern United States. Agron J 108(5): 1938-1943. https://doi.org/10.2134/agronj2016.03.0128

21. GU J, CHEN J, CHEN L, WANG Z, ZHANG H, YANG J 2015 Grain quality changes and responses to nitrogen fertilizer of japonica rice cultivars released in the Yangtze River Basin from the 1950s to 2000s. Crop J 3(4): 285-297.

https://doi.org/10.1016/j.cj.2015.03.007

22. XUE Y-F F, EAGLING T, HE J, ZOU C-Q Q, MCGRAIN SP, SHEWRY P R, ZHAO F-J J, MCGRATH SP, SHEWRY PR, ZHAO F-J J 2014 Effects of nitrogen on the distribution and chemical speciation of iron and zinc in pearling fractions of wheat grain. J Agric Food Chem 62(20): 4738-4746. https://doi.org/10.1021/jf500273x

23. KUTMAN UB, YILDIZ B, CAKMAK I 2011 Effect of nitrogen on uptake, remobilization and partitioning of zinc and iron throughout the development of durum wheat. Plant Soil 342(1-2): 149-164. https://doi.org/10.1007/s11104-010-0679-5
24. NIE Z, ZHAO P, WANG J, LI J, LIU H 2017 Absorption kinetics and subcellular fractionation of zinc in winter wheat in response to nitrogen supply. Front Plant Sci 8: 1435. https://doi.org/10.3389/fpls.2017.01435

25. ZHAO P, YANG F, SUI F, WANG Q, LIU H 2016 Effect of nitrogen fertilizers on zinc absorption and translocation in winter wheat. J Plant Nutr 39(9): 1311-1318. https://doi.org/10.1080/01904167.2015.1106560

26. BROADLEY M, WHITE P, HAMMOND J 2007 Zinc in plants. New Phytol 677-702. https://doi.org/10.1111/j.1469-8137.2007.01996.x

27. KAMALI S, RONAGHI A, KARIMIAN N 2010 Zinc Transformation in a Calcareous Soil as Affected by Applied Zinc Sulfate, Vermicompost, and Incubation Time. Commun Soil Sci Plant Anal 41(19): 2318-2329.

https://doi.org/10.1080/00103624.2010.508096

28. HUSSAIN S, MAQSOOD MA, RAHMATULLAH 2011 Zinc release characteristics from calcareous soils using diethylenetriaminepentaacetic acid and other organic acids. Commun Soil Sci Plant Anal 42(15): 1870-1881.

https://doi.org/10.1080/00103624.2011.587571

29. JOHNSON-BEEBOUT SE, GOLORAN JB, RUBIANES FHC, JACOB JDC, CASTILLO OB 2016 Zn uptake behavior of rice genotypes and its implication on grain $\mathrm{Zn}$ biofortification. Sci Rep 6: 38301. https://doi.org/10.1038/srep38301

30. SAHA S, CHAKRABORTY M, PADHAN D, SAHA B, MURMU S, BATABYAL K, SETH A, HAZRA GC, MANDAL B, BELL RW 2017 Agronomic biofortification of zinc in rice: Influence of cultivars and zinc application methods on grain yield and zinc bioavailability. F Crop Res 210: 52-60. https://doi.org/10.1016/j.fcr.2017.05.023

31. WISSUWA M, ISMAIL AM, GRAHAM RD 2008 Rice grain zinc concentrations as affected by genotype, native soil-zinc availability, and zinc fertilization. Plant Soil 306(1-2): 37-48. https://doi.org/10.1007/s11104-007-9368-4

32. OLSEN L I, PALMGREN MG 2014 Many rivers to cross: the journey of zinc from soil to seed. Front Plant Sci 5(February): 30. https://doi.org/10.3389/fpls.2014.00030 